\title{
Catalytic Conversion of Isopropanol and CO Oxidation in Presence of NiO Supported on Modified Cordierite
}

\author{
S.A. El-Molla ${ }^{* 1}$, G.A. El-Shobaky ${ }^{2}$, Y.M. Fahmy ${ }^{2}$ and H.G. El-Shobaky ${ }^{3}$ \\ ${ }^{I}$ Chemistry Department, Faculty of Education, Ain Shams University, Roxy, Heliopolis, Cairo 11757, Egypt \\ ${ }^{2}$ National Research Center, Dokki, Cairo, Egypt \\ ${ }^{3}$ Chemistry Department, Faculty of Science, Cairo University, Cairo, Egypt
}

\begin{abstract}
A commercial cordierite sample showed a small catalytic activity in isopropanol conversion carried out at 150$350{ }^{\circ} \mathrm{C}$ and no measurable activity in $\mathrm{CO}$ oxidation by $\mathrm{O}_{2}$. On the other hand, supporting $\mathrm{NiO}$ on $\mathrm{Al}_{2} \mathrm{O}_{3}-$ modified cordierite resulted in the formation of an active solid that having good catalytic activity in isopropanol conversion and $\mathrm{CO}$ oxidation by $\mathrm{O}_{2}$. These two reactions were carried out at 150-350 and $200{ }^{\circ} \mathrm{C}$, respectively. The results revealed that the catalyst containing $5 \%(\mathrm{w} / \mathrm{w}) \mathrm{NiO}$ showed the highest activity in the alcohol conversion and acted as selective dehydration catalyst. The catalyst sample containing $20 \% \mathrm{NiO}(\mathrm{w} / \mathrm{w})$ exhibited a good activity in $\mathrm{CO}$ oxidation by $\mathrm{O}_{2}$ which decreased progressively by increasing its calcination temperature within $350-600{ }^{\circ} \mathrm{C} . \mathrm{Al}_{2} \mathrm{O}_{3}$-treated cordierite dissolved a portion of $\mathrm{NiO}$ in its lattice, increasing the calcination temperature within $350-600{ }^{\circ} \mathrm{C}$ increases the dissolution of $\mathrm{NiO}$ in the matrix of $\mathrm{Al}_{2} \mathrm{O}_{3}$-modified cordierite system.
\end{abstract}

Keywords: EDX, Catalytic activity, $\mathrm{NiO} /$ Cordierite, $\mathrm{Al}_{2} \mathrm{O}_{3}$-treatment.

\section{INTRODUCTION}

Supported transition metal oxides constitute an interesting class of catalytic materials. These materials are used in many important industrial and environmental applications such as $\mathrm{CO}$ oxidation [1], $\mathrm{N}_{2} \mathrm{O}$ decomposition [2], methane steam reforming [3], dehydration and dehydrogenation of alcohols [4]. The catalytic activity and selectivity of the oxide catalyst can be modified by loading on different support materials $[5,6]$. The interaction between the support and transition metal oxide can take place via of formation metal aluminate in case of alumina- support, or solid solution in case of $\mathrm{MgO}$ support [7,8] having small catalytic activity if compared to metal oxide-supported solid. For this reason it is important to study the possibility of obtaining membranes which can not react with the catalytically active phase (transition metal oxide) and with low cost to be economic. Cordierite $\left(\mathrm{Mg}_{2} \mathrm{Al}_{4} \mathrm{Si}_{5} \mathrm{O}_{18}\right)$ is a crystalline magnesium aluminosilicate and is one of the phases of $\mathrm{MgO}-\mathrm{SiO}_{2}-\mathrm{Al}_{2} \mathrm{O}_{3}$ [9]. This material has low cost, low pressure drop in the exhaust system, good thermal resistance and low expansion coefficient [10]. These properties characterize cordierite as a potentially available material employed in electronic industry [10]. Also, cordierite is commercial material for high temperature catalyst applications, specially for automotive catalysts due its high mechanical stability and low thermal expansion coefficient [11]. As a rule cordierite has a low specific surface area that could be increased by treatment with

*Address correspondence to this author at the Chemistry Department, Faculty of Education, Ain Shams University, Roxy, Heliopolis, Cairo 11757, Egypt; Tel: +202 24558087; Fax: +202 22581243;

E-mail: saharelmolla@yahoo.com alumina [12]. The big surface area is very desirable. It has been shown that the increase of the total surface area of the monolith is the most effective way to increase the conversion of automotive pollutants for a given loading of precious metals [13]. Cordierite has been successfully used as a catalyst support for $\mathrm{Co}_{3} \mathrm{O}_{4}, \mathrm{Mn}_{2} \mathrm{O}_{3}, \mathrm{CuO}, \mathrm{Fe}_{2} \mathrm{O}_{3}$ and $\mathrm{NiO}[1$, $14,15]$.

This work aims at studying the physicochemical surface and catalytic properties of $\mathrm{NiO}$ supported on cordierite support material. The effects of extent of NiO-loading, calcination temperature and treating cordierite with $\mathrm{Al}_{2} \mathrm{O}_{3}$ using a washcoating technique on its physicochemical surface and catalytic properties have been investigated [16]. Different physicochemical surface and catalytic properties of $\mathrm{NiO}$ supported on $\mathrm{Al}_{2} \mathrm{O}_{3}$-modified cordierite support material were investigated using XRD, EDX, nitrogen adsorption at $-196{ }^{\circ} \mathrm{C}$ and catalytic conversion of isopropanol at $150-350{ }^{\circ} \mathrm{C}$ using the flow method and $\mathrm{CO}$ oxidation by $\mathrm{O}_{2}$ at $200{ }^{\circ} \mathrm{C}$.

\section{EXPERIMENTAL}

\section{Sample Preparation}

A commercial cordierite $\left(\mathrm{Mg}_{2} \mathrm{Al}_{4} \mathrm{Si}_{5} \mathrm{O}_{18}\right)$ supplied by Baikowski Inc. company was treated with $25 \% \mathrm{Al}_{2} \mathrm{O}_{3}(\mathrm{w} / \mathrm{w})$ using a washcoating technique. A given mass of aluminum ethoxide was dissolved in a convenient volume of ethanol and few drops of $\mathrm{HCl}(28 \%)$ and subjected to stirring for 60 min. A calculated amount of cordierite was then impregnated with alcoholic solution of aluminum ethoxide and stirred for $30 \mathrm{~min}$. at $60{ }^{\circ} \mathrm{C}$. The obtained solid was dried at $110^{\circ} \mathrm{C}$ till constant weight. The dried solid was used as a catalyst support for $\mathrm{NiO}$. The $\mathrm{Al}_{2} \mathrm{O}_{3}$-treated cordierite sample was then impregnated with calculated amounts of nickel nitrate 
dissolved in the least amounts of distilled water. The nominal compositions of the calcined impregnated solids were 5,10 and $20 \% \mathrm{NiO}(\mathrm{w} / \mathrm{w})$. The obtained solids were dried at $110{ }^{\circ} \mathrm{C}$ then calcined at $350-600{ }^{\circ} \mathrm{C}$ for $4 \mathrm{~h}$. All the chemicals employed were of analytical grade supplied by BDH Ltd.

\section{Characterization}

Phase analysis of the pure and variously treated specimens calcined in air at 350, 450 and $600{ }^{\circ} \mathrm{C}$ was performed by X-ray powder diffraction employing a BRUKER Axs D8 Advance, Germany. Patterns were run using Ni-filtered copper radiation $(\lambda=1.5404 \AA)$ at $40 \mathrm{kV}$ and $40 \mathrm{~mA}$. The crystallite size of $\mathrm{NiO}$ phase in different catalysts was calculated using the Scherrer equation [17] from line broadening profile analysis of the main diffraction lines of $\mathrm{NiO}$ phase at a scanning rate of 0.2 degree in 2 $\Theta /$ min. through TOPAZ2.Inc program.

Energy dispersive X-ray analysis (EDX) was carried out on Hitachi S-800 electron microscope with an attached kevex Delta system. The parameters were as follows: accelerating voltage $15 \mathrm{kV}$, accumulation time $100 \mathrm{~s}$, window width $8 \mu \mathrm{m}$. The surface molar composition was determined by the Asa method, Zaf-correction, Gaussian approximation.

The specific surface areas of the pure and variously treated samples were determined from nitrogen adsorption isotherms measured at $-196{ }^{\circ} \mathrm{C}$ using a conventional volumetric apparatus. All samples were degassed at $200{ }^{\circ} \mathrm{C}$ for 3 hours under a reduced pressure of $10^{-5}$ Torr before undertaking such measurements.

The catalytic activities of various investigated solids were determined by using each of oxidation of $\mathrm{CO}$ by $\mathrm{O}_{2}$ at $200^{\circ} \mathrm{C}$ and iso-propanol conversion at $150-300{ }^{\circ} \mathrm{C}$. The catalytic activities in $\mathrm{CO}$ oxidation by $\mathrm{O}_{2}$ were determined using a static method and the kinetics of this reaction were monitored by measuring the pressure of the reacting gases at different time intervals until no change in pressure was attained. Each catalyst sample (200 mg) was activated by heating at $300{ }^{\circ} \mathrm{C}$ for $2 \mathrm{~h}$. under a reduced pressure $10^{-6}$ Torr. A stoichiometric mixture of $\mathrm{CO}$ and $\mathrm{O}_{2}\left(\mathrm{CO}+1 / 2 \mathrm{O}_{2}\right)$ at a pressure of 2 Torr was used. The reaction product $\left(\mathrm{CO}_{2}\right)$ was removed from the reaction atmosphere by freezing at liquid nitrogen temperature. So, the percentage decrease of the reacting gases at a given time interval determines the percentage conversion of catalytic reaction at that time. The saturation vapor pressure of $\mathrm{CO}$ at $-196{ }^{\circ} \mathrm{C}$ being 160 Torr makes its liquefaction at that pressure improbable under the employed conditions (2 Torr) [7].

The catalytic conversion of isopropanol using various catalyst samples were determined at $150-350{ }^{\circ} \mathrm{C}$, the catalytic reaction being conducted in a flow reactor under atmospheric pressure. Thus, a $50 \mathrm{mg}$ catalyst sample was held between two glass wool plugs in a Pyrex glass reactor tube $20 \mathrm{~cm}$ long and $1 \mathrm{~cm}$ internal diameter packed with quartz fragments $2-3 \mathrm{~mm}$ length. The temperature of the catalyst bed was regulated and controlled to within $\pm 1{ }^{\circ} \mathrm{C}$. Argon gas was used as the diluent and the isopropyl alcohol vapor was introduced into the reactor through an evaporator/saturator containing the liquid reactant at constant temperature $35^{\circ} \mathrm{C}$. The flow rate of the carrier gas was maintained at $25 \mathrm{ml} / \mathrm{min}$.
Before carrying out such catalytic activity measurements, each catalyst sample was activated by heating at $300{ }^{\circ} \mathrm{C}$ in a current of argon for 2 hours then cooled to the catalytic reaction temperature. The reaction products in the gaseous phase were analyzed chromatographically using PerkinElmer Auto System XL Gas Chromatograph fitted with a flame ionization detector. The column used was fused silica glass capillary column type PE-CW length 15 m-1.0 UM Perkin-Elmer corp.

\section{RESULTS AND DISCUSSION}

\section{EDX Investigation of Different Solids}

Energy dispersive $\mathrm{x}$-ray (EDX) investigation of untreated cordierite, $20 \%(\mathrm{w} / \mathrm{w}) \mathrm{NiO} /$ cordierite, $25 \% \mathrm{Al}_{2} \mathrm{O}_{3}$-cordierite and $20 \% \mathrm{NiO} / 25 \% \mathrm{Al}_{2} \mathrm{O}_{3}$-cordierite samples calcined at 350 $600{ }^{\circ} \mathrm{C}$ was carried out. The atomic abundance of nickel, aluminum, magnesium, silicon and oxygen species present in the uppermost surface layers of the calcined solids is given in Table 1. The atomic abundance of all cordierite constituents in its whole mass was calculated based on the formula of untreated cordierite samples and those treated with $20 \mathrm{wt} \% \mathrm{NiO}$ and/or $25 \mathrm{wt} \% \quad \mathrm{Al}_{2} \mathrm{O}_{3}$. The data obtained are also given in Table $\mathbf{1}$. Inspection of the results given in Table 1 reveals the following: (i) The calculated concentration of atoms constituting untreated cordierite in the bulk is similar to that found in the uppermost surface layers (from EDX data). This finding indicates the homogeneous structure of investigated cordierite sample. (ii) The concentration of $\mathrm{Ni}$ species present in the uppermost surface layers (determined by EDX) of cordierite samples treated with $20 \% \mathrm{NiO}$ calcined at $350{ }^{\circ} \mathrm{C}$ are slightly smaller than those present in the bulk of solid(calculated). The difference is $16 \%$. It is also found that the concentration of $\mathrm{Ni}$ species present in the uppermost surface layers determined by EDX decreases with increasing the calcination temperature from 350 to $600{ }^{\circ} \mathrm{C}$. It is predicted that, the surface concentration of $\mathrm{Ni}$ species should be greater than that present in the bulk because the samples were prepared by wet impregnation method [18]. However, this speculation has not been observed experimentally in case of $\mathrm{NiO} /$ cordierite system. This discrepancy could be attributed to the dissolution of a significant portion of $\mathrm{NiO}$ present in the matrix of cordierite support material. In fact, the EDX investigation of $\mathrm{NiO} /$ cordierite-alumina system calcined at different calcination temperatures (Table 1) shows clearly that the rise in the calcination temperature for the catalyst sample from 350 to $450{ }^{\circ} \mathrm{C}$ led to an increases in the amount of $\mathrm{Ni}$ species dissolved in the matrix of the cordierite. In fact, it has been reported by El-Shobaky et al. that cordierite support material can dissolve different amounts of $\mathrm{Mn}_{2} \mathrm{O}_{3}, \mathrm{Fe}_{2} \mathrm{O}_{3}$ and $\mathrm{CuO}$ to an extent dependent mainly on the nature of transition metal species and calcination temperature $[1,14,15]$. (iii) The concentration of Al species added to cordierite was found to be slightly higher than that present in the bulk, the difference attained 5\%. (iv) The comparison between the surface concentration of $\mathrm{Ni}$ species in the untreated and $\mathrm{Al}_{2} \mathrm{O}_{3}$-treated cordierite shows clearly that $\mathrm{Al}_{2} \mathrm{O}_{3}$-treatment increases effectively the extent of $\mathrm{Ni}$ species present in the uppermost surface layers of the cordierite support material. This finding might be attributed to the possible effective increase in the dispersion power of 
Table 1. Surface Molar Composition of Cordierite, NiO/Cordierite, $\mathrm{Al}_{2} \mathrm{O}_{3}$-Cordierite and $\mathrm{NiO} / \mathrm{Al}_{2} \mathrm{O}_{3}$-Cordierite Solids Determined by EDX

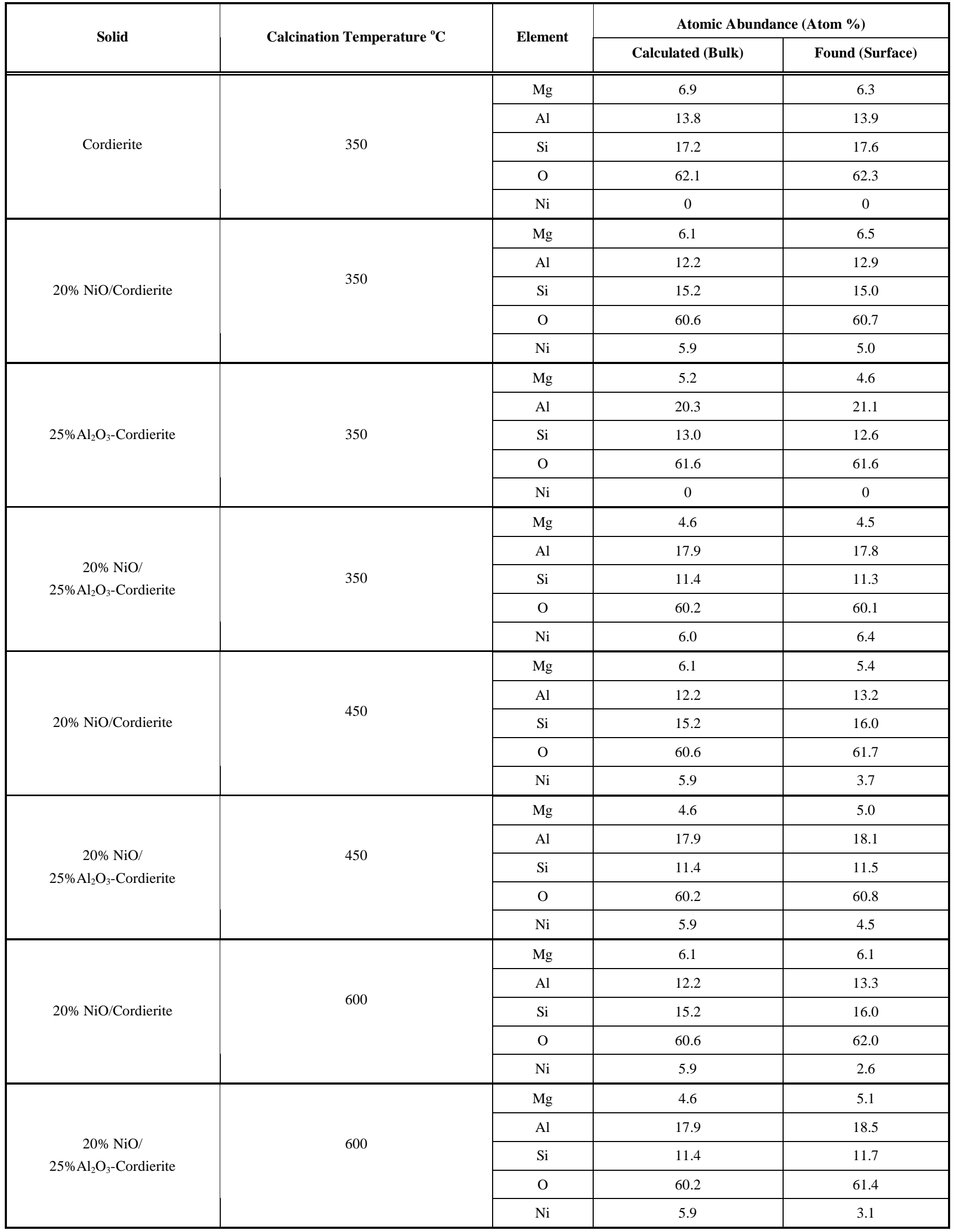


$\mathrm{Al}_{2} \mathrm{O}_{3}$-treated solid towards nickel species. This influence might result from the possible appreciable increase in the specific surface area of the $\mathrm{Al}_{2} \mathrm{O}_{3}$-treated cordierite solid. This speculation will be confirmed later in the next section of the present work. Increasing the calcination temperature of all nickel containing solids from 350 to $600{ }^{\circ} \mathrm{C}$ resulted in a progressive decrease in surface concentration of nickel. This decrease might result from an enhanced diffusion of nickel species from top surface layers towards the bulk of calcined solids. This process should be accompanied by an effective dissolution of nickel species in the matrix of the support material.

\section{XRD Investigation of Different Investigated Solids}

X-Ray powder diffractograms of cordierite support material treated with 10 and $20 \% \mathrm{NiO}$ oxide calcined at 350 , 450 and $600{ }^{\circ} \mathrm{C}$ were determined. X-Ray diffractograms of cordierite support material being treated with $25 \% \mathrm{Al}_{2} \mathrm{O}_{3}$ and $5,10,20 \% \mathrm{NiO}$ and calcined at 350,450 and $600{ }^{\circ} \mathrm{C}$ were carried out. Figs. (1-3) depicts the diffractograms of various solids calcined at 350,450 and $600{ }^{\circ} \mathrm{C}$, respectively. Examination of Figs. (1-3) shows the following: (i) $\mathrm{Al}_{2} \mathrm{O}_{3}$ treatment of cordierite followed by calcination at $350-600{ }^{\circ} \mathrm{C}$ led to a drop in the degree of crystallinity of the cordierite i.e. the relative intensity of all diffraction lines of the cordierite suffered a drastic decrease. This finding indicates clearly that $\mathrm{Al}_{2} \mathrm{O}_{3}$ brought about a significant structure collapse of cordierite structure more than $50 \%$ as evidenced from the significant drop (50\%) in the relative intensity of all diffraction lines of cordierite solid. (ii) All diffraction lines of $\mathrm{NiO}$ were detected in the diffractograms of $\mathrm{NiO}$ containing solids even those treated with $5 \% \mathrm{NiO}$. (iii) The relative intensity of diffraction lines of $\mathrm{NiO}$ increases progressively by increasing the $\mathrm{NiO}$ content. The crystallite size and degree of crystallinity of $\mathrm{NiO}$ present in different solids calcined at different temperatures were calculated and the results obtained are given in Table 2. This table shows clearly that $\mathrm{NiO}$ phase existed as nanocrystalline material. (iv) Although the concentration of $5 \% \mathrm{NiO}$ in the $\mathrm{Al}_{2} \mathrm{O}_{3^{-}}$ treated cordierite calcined at $600{ }^{\circ} \mathrm{C}$ seems to be beyond the detection limit of $\mathrm{x}$-ray diffractometer, all diffraction lines of this phase were detected (c.f. Fig. 3). This finding might suggest an enriched existence of this phase on top surface layers of the calcined solid. This conclusion has been reached at by EDX investigation previously given in the present work. (v) Examination of Table 2 shows also that $\mathrm{Al}_{2} \mathrm{O}_{3}$ treatment of NiO-containing cordierite brought about a significant drop in the degree of crystallinity of $\mathrm{NiO}$ with subsequent decrease in its crystallite size.

\section{Specific Surface Areas of Different Investigated Solids}

The specific surface area $\left(\mathrm{S}_{\mathrm{BET}}\right)$ of cordierite support material and samples treated with $\mathrm{Al}_{2} \mathrm{O}_{3}$ and $\mathrm{NiO}$ oxides and being calcined at 350,450 and $600{ }^{\circ} \mathrm{C}$ were determined. The obtained results are given in Table $\mathbf{3}$. Inspection of Table $\mathbf{3}$ reveals the following: (i) The $S_{\mathrm{BET}}$ of cordierite support material is very small increasing tremendously with treatment with $25 \% \mathrm{Al}_{2} \mathrm{O}_{3}$ calcined at $350-600{ }^{\circ} \mathrm{C}$. The increase in the $\mathrm{S}_{\mathrm{BET}}$ of cordierite due to alumina treatment reaches to 30 -fold. (ii) Increasing the calcination temperature from 350 to $450{ }^{\circ} \mathrm{C}$ and from 450 to $600{ }^{\circ} \mathrm{C}$ for aluminacordierite solids decreases their surface areas with 9 and $19 \%$, respectively. These results show the high thermal stability of alumina-cordierite samples.(iii) Treating alumina -cordierite samples with 10 and $20 \% \mathrm{NiO}$ followed by calcination at 350,450 and $600{ }^{\circ} \mathrm{C}$ led to a further small increase in the $\mathrm{S}_{\mathrm{BET}}$ of the treated samples. The observed increase in the specific surface area of cordierite due to alumina treatment is expected not only because of the relatively big surface area of $\mathrm{Al}_{2} \mathrm{O}_{3}$ compared to that of cordierite but also because of the method of preparation which led to the formation of very fine crystallites.

The significant increase in the specific surface areas of cordierite samples due to their treatment with $\mathrm{Al}_{2} \mathrm{O}_{3}$ and/or $\mathrm{NiO}$ oxides is expected to modify their catalytic properties.

\section{Catalytic Oxidation of $\mathrm{CO}$ by $\mathrm{O}_{2}$ Over Different Solids}

Preliminary experiments showed that the employed untreated cordierite and the $\mathrm{Al}_{2} \mathrm{O}_{3}$-treated solids exhibited no measurable activity in $\mathrm{CO}$ oxidation by $\mathrm{O}_{2}$ even by carrying out the reaction at relatively high temperature reaching to

Table 2. The Crystallite Size and Degree of Crystallinity of NiO Phase in Different Investigated Solids

\begin{tabular}{|c|c|c|c|}
\hline Sample & Calcination Temperature & Crystallite Size of NiO (nm) $^{\mathbf{b}}$ & Degree of Crystallinity (a.u) $^{\mathbf{a}}$ \\
\hline \hline $10 \% \mathrm{NiO} /$ cordierite & $350{ }^{\circ} \mathrm{C}$ & 20.7 & 40.8 \\
\hline $20 \% \mathrm{NiO} /$ cordierite & $350{ }^{\circ} \mathrm{C}$ & 22.3 & 92.7 \\
\hline $10 \% \mathrm{NiO} /$ cordierite & $450{ }^{\circ} \mathrm{C}$ & 16.5 & 36 \\
\hline $20 \% \mathrm{NiO} /$ cordierite & $450{ }^{\circ} \mathrm{C}$ & 25.6 & 35.5 \\
\hline $10 \% \mathrm{NiO} /$ cordierite & $600{ }^{\circ} \mathrm{C}$ & 20.8 & 20.4 \\
\hline $10 \% \mathrm{NiO} /$ cordierite- $25 \% \mathrm{Al}_{2} \mathrm{O}_{3}$ & $350{ }^{\circ} \mathrm{C}$ & 23 & 13 \\
\hline $10 \% \mathrm{NiO} /$ cordierite- $25 \% \mathrm{Al}_{2} \mathrm{O}_{3}$ & $450{ }^{\circ} \mathrm{C}$ & 3 & 29.1 \\
\hline $5 \% \mathrm{NiO} /$ cordierite- $25 \% \mathrm{Al}_{2} \mathrm{O}$ & $600{ }^{\circ} \mathrm{C}$ & 17.7 & 20 \\
\hline $10 \% \mathrm{NiO} /$ cordierite- $25 \% \mathrm{Al}_{2} \mathrm{O}_{3}$ & $600{ }^{\circ} \mathrm{C}$ & 36.7 & 22.2 \\
\hline $20 \% \mathrm{NiO} /$ cordierite- $25 \% \mathrm{Al}_{2} \mathrm{O}_{3}$ & $600{ }^{\circ} \mathrm{C}$ & & 20 \\
\hline
\end{tabular}

${ }^{\mathrm{a}}$ The areas of the main diffraction lines of $\mathrm{NiO}$ phase were taken as a measure of degree of crystallinity of this phase.

${ }^{\mathrm{b}} \mathrm{The}$ hkl of the main diffraction lines of $\mathrm{NiO}$ phase (012) was considered in calculating the crystallite size of NiO phase. 


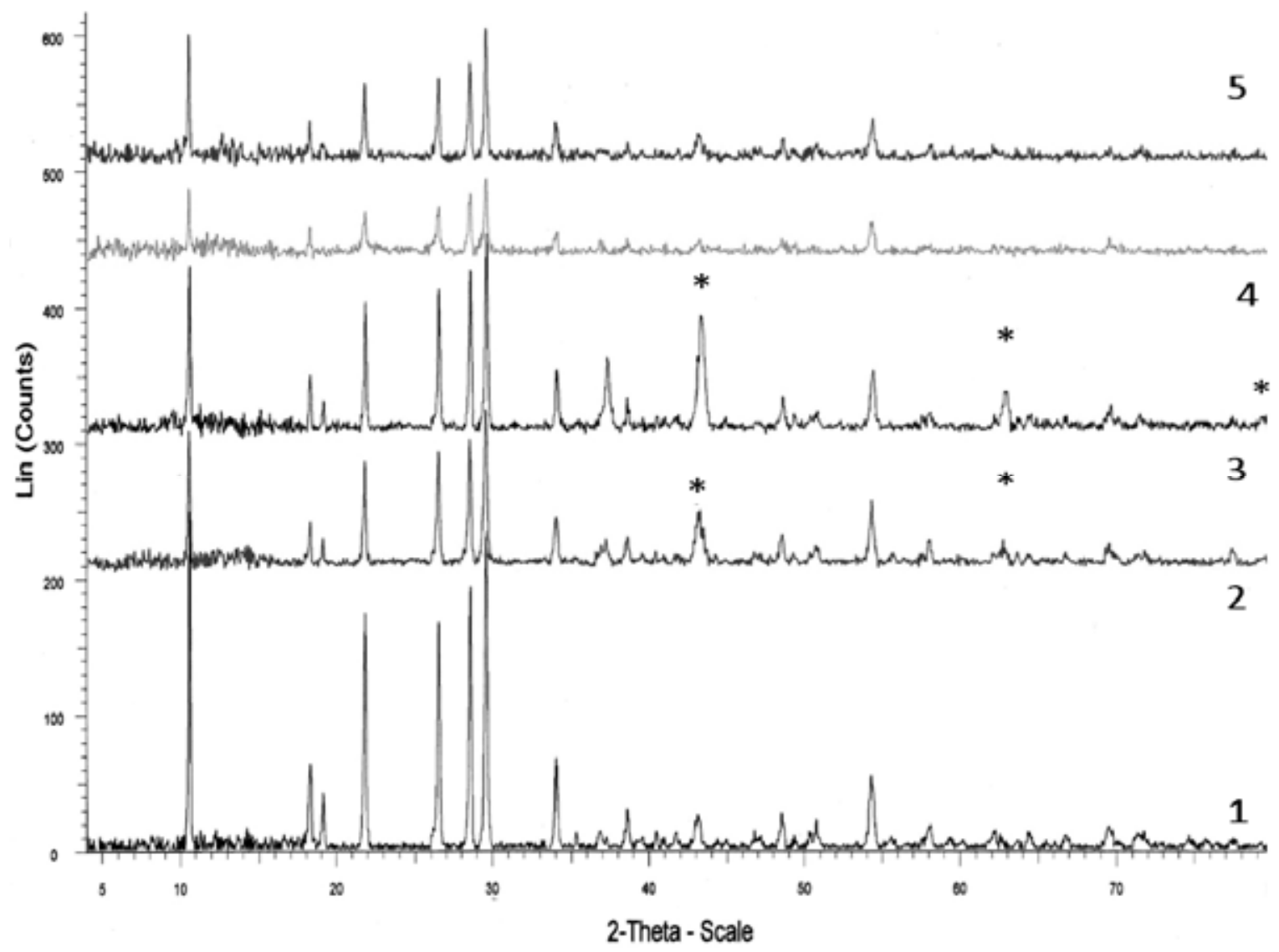

Fig. (1). XRD diffractograms of: (1) Cordierite, (2) $10 \% \mathrm{NiO} /$ Cordierite, (3) $20 \% \mathrm{NiO} / \mathrm{Cordierite}$, (4) Cordierite- 25\%alumina and (5) $10 \%$ $\mathrm{NiO} /$ Cordierite- $25 \%$ alumina precalcined at $350{ }^{\circ} \mathrm{C} . *$ For $\mathrm{NiO}$ phase and the other lines are related to cordierite phase.

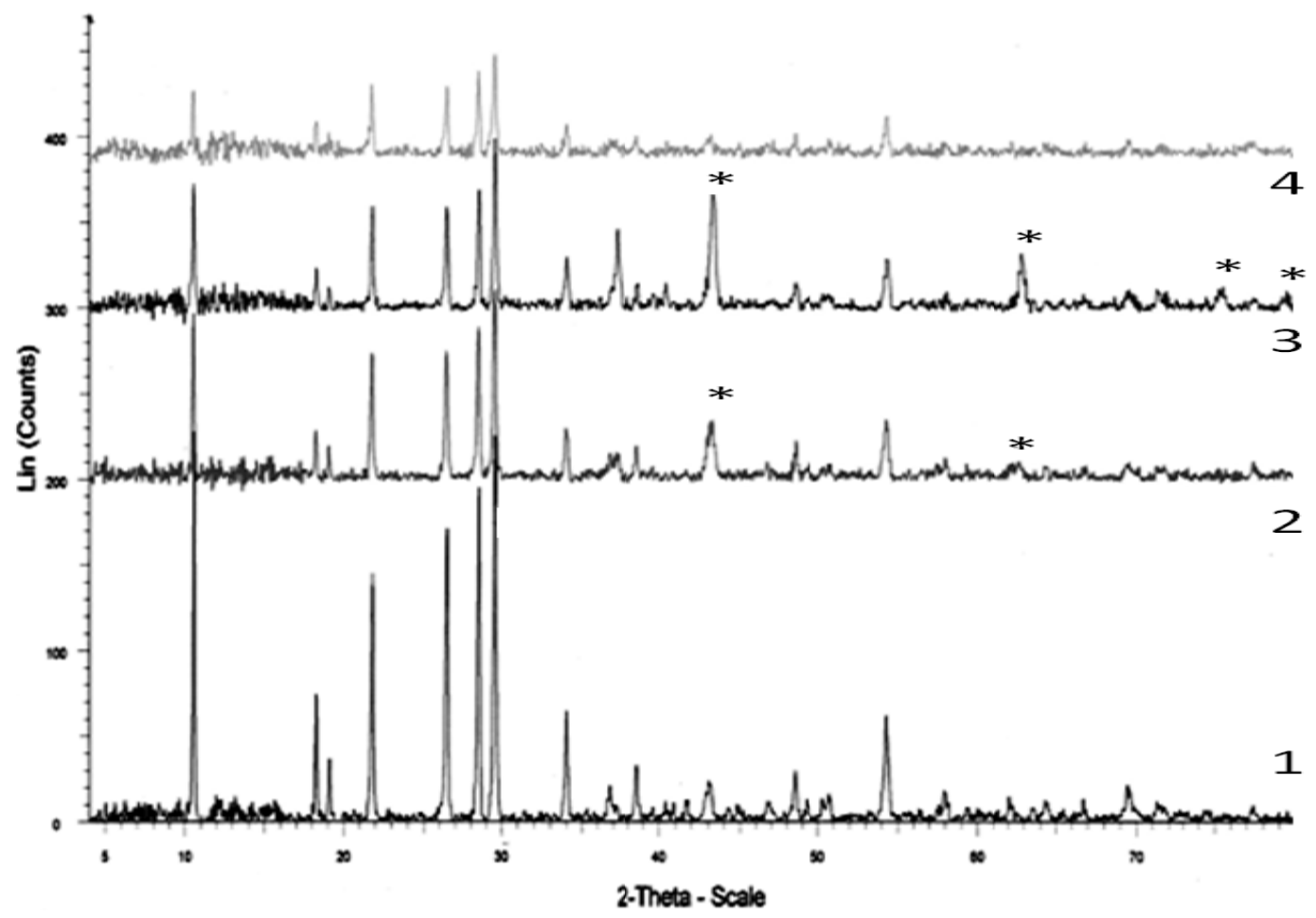

Fig. (2). XRD diffractograms of: (1) Cordierite, (2) 10\% NiO/Cordierite, (3) 20\% NiO/Cordierite and (4) 10\% NiO/Cordierite-25\% alumina precalcined at $450^{\circ} \mathrm{C}$. * For $\mathrm{NiO}$ phase and the other lines are related to cordierite phase. 


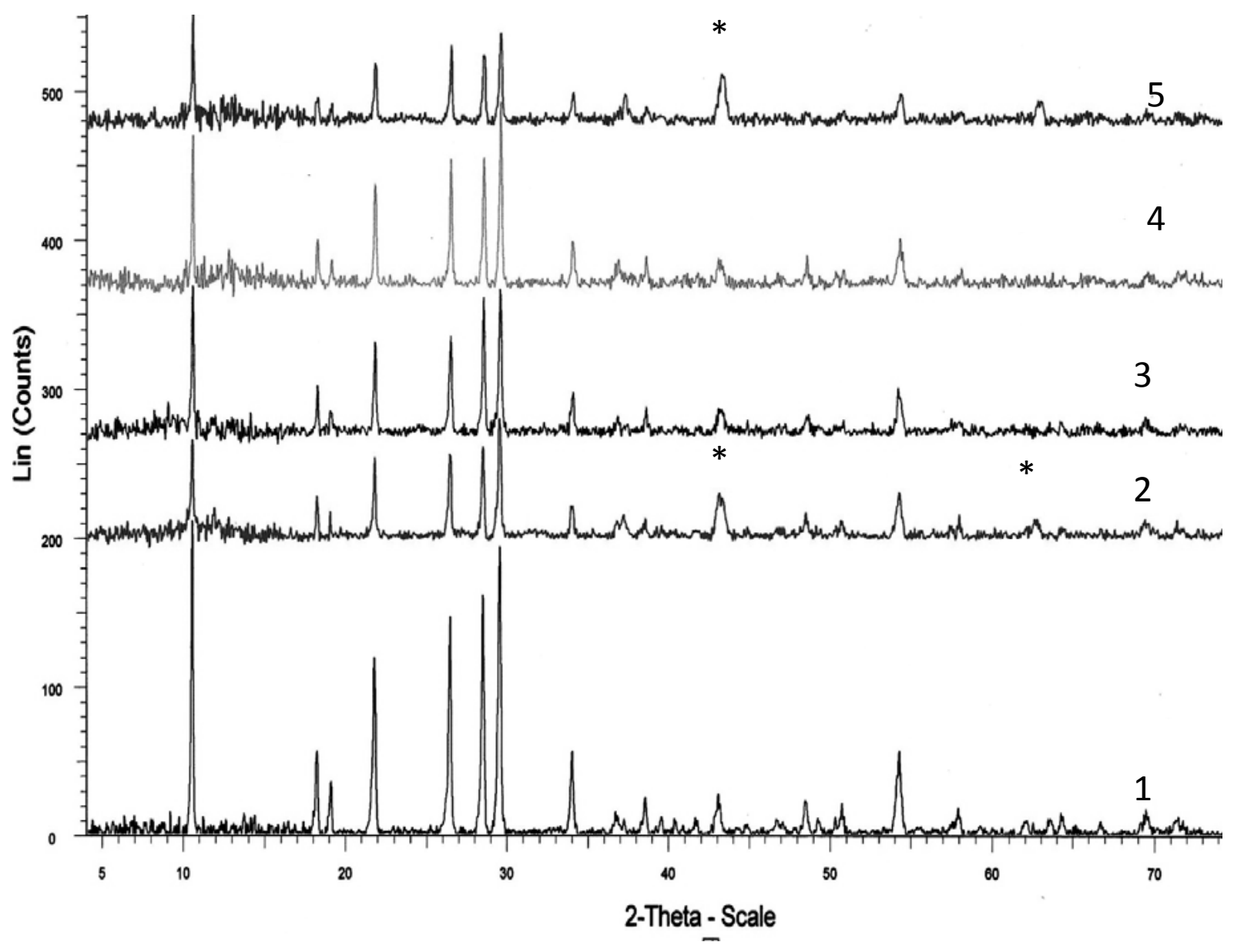

Fig. (3). XRD diffractograms of: (1) Cordierite, (2) $10 \% \mathrm{NiO} /$ Cordierite, (3) 5\% NiO/Cordierite-25\%alumina, (4) 10\% NiO/Cordierite$25 \%$ alumina and (5) $20 \% \mathrm{NiO} /$ Cordierite-25\% alumina precalcined at $600{ }^{\circ} \mathrm{C}$. ${ }^{*}$ For $\mathrm{NiO}$ phase and the other lines are related to cordierite phase.

$300{ }^{\circ} \mathrm{C}$. So, the cordierite acted as a catalyst support for $\mathrm{CO}$ oxidation by $\mathrm{O}_{2}$. The catalytic oxidation of $\mathrm{CO}$ by $\mathrm{O}_{2}$ was carried out at $200{ }^{\circ} \mathrm{C}$ over nickel/ cordierite-alumina system containing $20 \% \mathrm{NiO}$ and calcined at 350,450 and $600{ }^{\circ} \mathrm{C}$. The catalytic reaction was found to follow first- order kinetics in all cases. The slope of the first order plots (not given) determines the reaction rate constant $\mathrm{k}$ at a given temperature over a given catalyst sample. The computed $\mathrm{k}$ values were found to be $7,2.4$ and $0.7 \times 10^{-2} \mathrm{~min}^{-1} \cdot \mathrm{g}^{-1}$ for the reaction carried out at $200{ }^{\circ} \mathrm{C}$ over the samples calcined at 350,450 and $600{ }^{\circ} \mathrm{C}$, respectively. This finding indicates clearly that the rise in precalcination temperature of nickel/cordierite-alumina system suffered a drastic decrease in its activity towards catalytic oxidation of $\mathrm{CO}$ by $\mathrm{O}_{2}$ because of increasing its calcination temperature from 350 to $450{ }^{\circ} \mathrm{C}$. The rise in the precalcination temperature above this limit brought about a limited decrease in its catalytic activity. The observed remarkable decrease in the catalytic activity might indicate a significant decrease in the concentration of active sites involved in chemisorption and catalysis of $\mathrm{CO}$ oxidation by $\mathrm{O}_{2}$. This decrease could be attributed to a significant decrease in surface concentration of $\mathrm{NiO}$ (catalytically active constituent in $\mathrm{CO}$ oxidation reaction). This decrease could result from the dissolution of a significant portion of $\mathrm{NiO}$ present in the matrix of the cordierite support material. In fact, the EDX investigation of
$\mathrm{NiO} /$ cordierite-alumina system calcined at different temperatures (Table 1) shows clearly that the rise in the calcination temperature for the catalyst sample from 350 to $450{ }^{\circ} \mathrm{C}$ led to a considerable decrease in surface concentration of $\mathrm{Ni}$ species present in the top surface layers of the treated solids.

\section{Catalytic Conversion of Isopropanol Over Different Investigated Solids}

\section{Effect of Extent of NiO Loading on the Activity NiO/Cordierite System Towards Isopropanol Conversion}

The catalytic conversion of isopropanol was carried out over 10 and $20 \% \mathrm{NiO} /$ cordierite solids calcined at 350,450 and $600{ }^{\circ} \mathrm{C}$. The same catalytic reaction was also carried out over cordierite material calcined at the same temperatures. Fig. (4) shows the effect of extent of $\mathrm{NiO}$ loading of $\mathrm{NiO} /$ cordierite system calcined at $350-600{ }^{\circ} \mathrm{C}$ on its catalytic activity expressed as the total conversion. The same figure shows the selectivity towards propene formation for the reaction carried out at $275^{\circ} \mathrm{C}$. It is noticed from Fig. (4) that: (i) the cordierite exhibited a measurable catalytic activity, which increased by increasing the calcination temperature from 350 to $450{ }^{\circ} \mathrm{C}$ and then decreased with increasing the calcination temperature to $600{ }^{\circ} \mathrm{C}$. (ii) Supporting $10 \% \mathrm{NiO}$ on cordierite material calcined at 450 and $600{ }^{\circ} \mathrm{C}$ increased 
Table 3. The Specific Surface Areas $S_{\mathrm{BET}}$ of Different Investigated Adsorbents at Different Calcination Temperatures

\begin{tabular}{|c|c|c|}
\hline Sample & $\begin{array}{c}\text { Calcination } \\
\text { Temperature }\end{array}$ & $\mathbf{S}_{\text {BET }},\left(\mathbf{m}^{2} / \mathbf{g}\right)$ \\
\hline \hline untreated cordierite & $350{ }^{\circ} \mathrm{C}$ & 4 \\
\hline$+25 \% \mathrm{Al}_{2} \mathrm{O}_{3}$ & $350{ }^{\circ} \mathrm{C}$ & 127 \\
\hline$+25 \% \mathrm{Al}_{2} \mathrm{O}_{3}+10 \% \mathrm{NiO}$ & $350{ }^{\circ} \mathrm{C}$ & 131.8 \\
\hline$+25 \% \mathrm{Al}_{2} \mathrm{O}_{3}+20 \% \mathrm{NiO}$ & $350{ }^{\circ} \mathrm{C}$ & 135.8 \\
\hline$+25 \% \mathrm{Al}_{2} \mathrm{O}_{3}$ & $450{ }^{\circ} \mathrm{C}$ & 115 \\
\hline$+25 \% \mathrm{Al}_{2} \mathrm{O}_{3}+10 \% \mathrm{NiO}$ & $450{ }^{\circ} \mathrm{C}$ & 117 \\
\hline$+25 \% \mathrm{Al}_{2} \mathrm{O}_{3}+20 \% \mathrm{NiO}$ & $450{ }^{\circ} \mathrm{C}$ & 120 \\
\hline$+25 \% \mathrm{Al}_{2} \mathrm{O}_{3}$ & $600{ }^{\circ} \mathrm{C}$ & 92.9 \\
\hline$+25 \% \mathrm{Al}_{2} \mathrm{O}_{3}+10 \% \mathrm{NiO}$ & $600{ }^{\circ} \mathrm{C}$ & 93.4 \\
\hline$+25 \% \mathrm{Al}_{2} \mathrm{O}_{3}+20 \% \mathrm{NiO}$ & $600{ }^{\circ} \mathrm{C}$ & 94.2 \\
\hline
\end{tabular}

the catalytic activity (expressed as a total conversion \%) and decreases the dehydration selectivity. Also, Supporting $20 \%$ $\mathrm{NiO}$ on cordierite material calcined at $350{ }^{\circ} \mathrm{C}$ increased the catalytic activity and decreases the dehydration selectivity (iii) Increasing the calcination temperature from 350 to 450 ${ }^{\circ} \mathrm{C}$ increased the catalytic activity of $\mathrm{NiO} /$ cordierite deceased by increasing the calcination temperature to $600{ }^{\circ} \mathrm{C}$ without much affecting the dehydration selectivity. (iv) The increase of $\mathrm{NiO}$ content from $10 \%$ to $20 \%$ in the solids calcined at $350{ }^{\circ} \mathrm{C}$ led to a measurable decrease in their catalytic activity with a no effect in the dehydration selectivity.

So, NiO/cordierite system acted as multi component catalyst where the cordierite material itself has a measurable catalytic activity in alcohol conversion while it acted as a catalyst support in $\mathrm{CO}$ oxidation by $\mathrm{O}_{2}$. The observed catalytic activity of unloaded cordierite solid which acted as selective catalyst for the dehydration of the investigated alcohol could be attributed to the presence of alumina-silicamagnesia components. These components behave normally as dehydration catalyst. The observed increase in the catalytic activity of unsupported cordierite by increasing its calcination temperature from 350 to $450{ }^{\circ} \mathrm{C}$ could be attributed to an effective increase in the concentration of active sites involved in dehydration reaction while the significant drop in its activity upon heating to $600{ }^{\circ} \mathrm{C}$ could be attributed to an effective decrease in the surface acidity [19].

The observed increase in the catalytic activity of $\mathrm{NiO} /$ cordierite system due to increasing its calcination temperature from 350 to $450{ }^{\circ} \mathrm{C}$ expressed a corresponding increase in the concentration of active sites involved in isopropanol conversion. EDX investigation (Table 1) revealed that the rise in calcination temperature from 350 to $450{ }^{\circ} \mathrm{C}$ led to a measurable decrease in the concentration of surface $\mathrm{Ni}$-species, not involved in the dehydration process. This decrease is expected to be accompanied by an increase in the concentration of the active sites involved in the dehydration of isopropanol (surface alumina) present in the
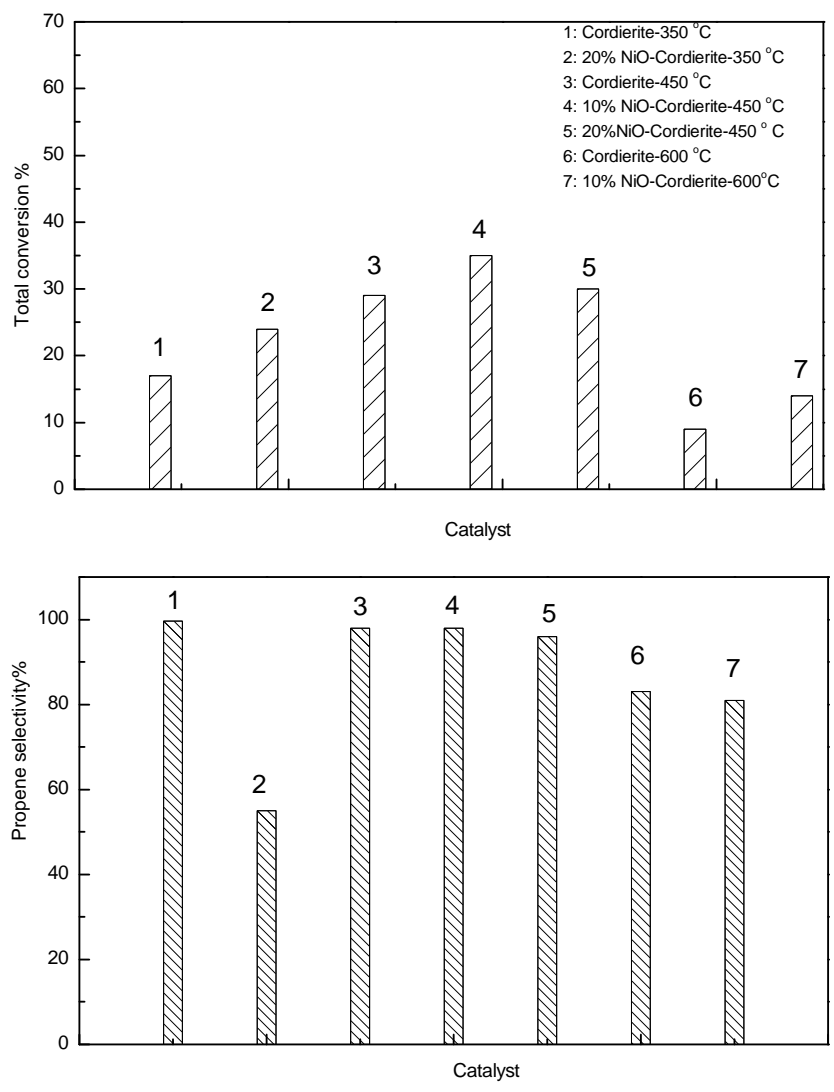

Fig. (4). Effect of extent of $\mathrm{NiO}$ loading and calcination temperature on the total conversion and selectivity towards propene formation using different catalysts for the reaction carried out at $275^{\circ} \mathrm{C}$.

cordierite material. In other words, $\mathrm{NiO}$ might block a portion of active sites taking part in the dehydration process, the removal of which is expected to increase the portion of active sites participating in the dehydration reaction. The measurable decrease in the activity of $\mathrm{NiO} /$ cordierite system by increasing the calcination temperature up to $600{ }^{\circ} \mathrm{C}$ might be attributed to both an effective removal of surface $\mathrm{OH}$ groups, involved in the dehydration reaction and an effective increase in the degree of crystallinity and crystallite size of the catalyst constituents. The decrease in the catalytic activity expressed as total conversion by increasing $\mathrm{NiO}$ content from 10 to $20 \%$ could be attributed to blocking of some surface active sites (alumina constituents of the cordierite material) by $\mathrm{NiO}$ not directly involved in the dehydration process of isopropanol.

\section{Effect of $\mathrm{Al}_{2} \mathrm{O}_{3}$ Treatment on the Activity NiO/Cordierite System Towards Isopropanol Conversion}

The effect of treating cordierite material with $\mathrm{Al}_{2} \mathrm{O}_{3}$, by washcoating method, on the activity and selectivity of both cordierite and $\mathrm{NiO} /$ cordierite systems, towards dehydration and dehydrogenation of isopropanol, were investigated. The $\mathrm{NiO}$ contents present were 5, 10 and $20 \%$ (w/w). Figs. $(\mathbf{5}, \mathbf{6})$ show the effect of $\mathrm{Al}_{2} \mathrm{O}_{3}$-treatment on the activity and selectivity of cordierite and $\mathrm{NiO}$ /cordierite systems and extent of $\mathrm{NiO}$ loading in $\mathrm{NiO} / \mathrm{Al}_{2} \mathrm{O}_{3}$-cordierite system calcined at 350,450 and $600{ }^{\circ} \mathrm{C}$. It is well-known that alumina acts as an active dehydration catalyst [20]. It is 

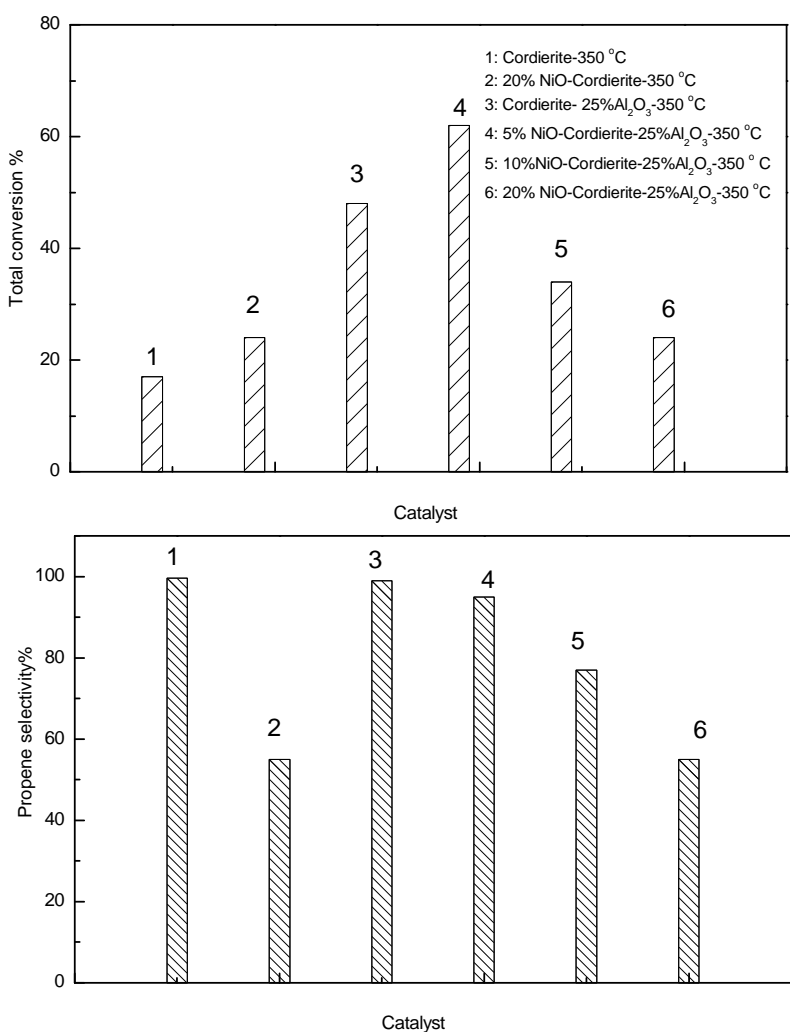

Fig. (5). Effect of alumina treatment and amount of $\mathrm{NiO}$ added on the total conversion and selectivity towards propene formation for the reaction carried out at $275^{\circ} \mathrm{C}$ over various solids calcined at 350 ${ }^{\circ} \mathrm{C}$.

noticed from Figs. (5, 6) that: (i) $\mathrm{Al}_{2} \mathrm{O}_{3}$ treatment much increased the catalytic performance of both cordierite and $\mathrm{NiO} /$ cordierite systems. The increase was, however, more pronounced in case of the cordierite solid. The $\%$ increase in the catalytic activity measured at $275{ }^{\circ} \mathrm{C}$ for the employed cordierite due to its treatment with $\mathrm{Al}_{2} \mathrm{O}_{3}$ attained 182 and $244 \%$ for the catalysts calcined at 350 and $600{ }^{\circ} \mathrm{C}$, respectively. The observed significant increase in the catalytic activity of cordierite and $\mathrm{NiO}$-cordierite solids due to treating with alumina can be directly attributed to the significant and considerable increase in the specific surface area of the treated catalyst (c.f. Table 3 ). This increase could also be attributed to the presence of free alumina on top surface layers of the treated catalyst. This behavior could be evidenced from EDX investigation of alumina-treated solids (c.f. Table 1). In fact the surface concentration of aluminum species increased from 13.9 to 21.1 atom $\%$ upon treating the cordierite solid with $25 \% \mathrm{Al}_{2} \mathrm{O}_{3}$. (ii) The presence of the smallest amount of $\mathrm{NiO}(5 \%)$ in the $\mathrm{Al}_{2} \mathrm{O}_{3}$-treated $\mathrm{NiO} /$ cordierite being calcined at 350 or $600{ }^{\circ} \mathrm{C}$ much increased the catalytic activity, the increase attained 29 and $87 \%$ for the catalyst at 350 and $600{ }^{\circ} \mathrm{C}$, respectively. The catalytic activity decreased progressively by increasing the extent of $\mathrm{NiO}$ to 10 and $20 \%$. The observed decrease in the catalytic activity of $\mathrm{Al}_{2} \mathrm{O}_{3}$-treated $\mathrm{NiO}$ /cordierite above $5 \%$ $\mathrm{NiO}$ might be attributed to a possible blocking of some active sites (surface alumina) by $\mathrm{NiO}$ which may contribute directly in the dehydrogenation of the investigated alcohol. (iii) Increasing the calcination temperature of untreated cordierite up to $600{ }^{\circ} \mathrm{C}$ brought about a considerable decrease in its catalytic activity (c.f. Fig. 6). However alumina treatment of cordierite followed by calcination at $600{ }^{\circ} \mathrm{C}$ led to a limited decrease in its catalytic activity. This finding justified the use of alumina treatment by washcoating method in increasing the thermal stability of the treated cordierite.
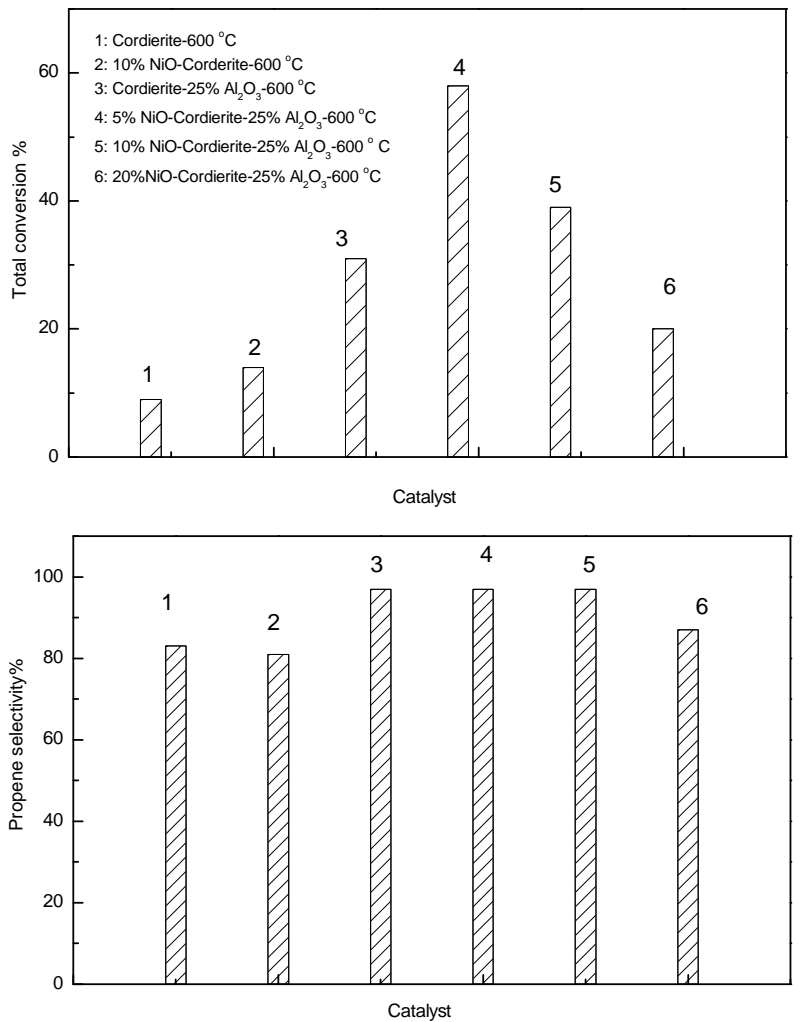

Fig. (6). Effect of alumina treatment and amount of $\mathrm{NiO}$ added on the total conversion and selectivity towards propene formation for the reaction carried out at $275^{\circ} \mathrm{C}$ over various solids calcined at 600 ${ }^{\circ} \mathrm{C}$.

\section{CONCLUSIONS}

The following are the main conclusions that may be drawn from the obtained results:

A commercial cordierite sample measured very small specific surface area had no measurable catalytic activity in $\mathrm{CO}$ oxidation by $\mathrm{O}_{2}$. However, it showed relatively small catalytic activity in iso-propanol conversion. $\mathrm{Al}_{2} \mathrm{O}_{3}-$ treatment of the cordierite sample and $\mathrm{NiO}$-cordierite solids using washcoating method brought about a considerable increase in their $S_{\text {BET }}$ which reached about 30-fold. This treatment brought about a significant increase in the catalytic activity of both cordierite and $\mathrm{NiO}$-cordierite solids. Untreated cordierite, alumina-treated cordierite, and $\mathrm{NiO}$ cordierite solids acted as selective dehydration catalysts. The activity of cordierite and $\mathrm{NiO}$-cordierite with or without alumina treatment and calcined within $350-600{ }^{\circ} \mathrm{C}$ decreased progressively. The decrease was, however, more pronounced in case of the solids not treated with alumina. The presence of the smallest amount of $\mathrm{NiO}(5 \%)$ in the alumina treated solids much increased the catalytic activity which decreased 
by increasing the extent of $\mathrm{NiO}$ loading above this limit. The cordierite support material and $\mathrm{Al}_{2} \mathrm{O}_{3}$-treated cordierite acted as dehydration catalyst with selectivity above $90 \%$. The increase of $\mathrm{NiO}$ content within $(5-20 \%)$ in $\mathrm{NiO} /$ Cordierite- $\mathrm{Al}_{2} \mathrm{O}_{3}$ followed by calcination at 350 to $600{ }^{\circ} \mathrm{C}$ resulted in a progressive increase in the selectivity towards dehydrogenation of alcohol. $\mathrm{Al}_{2} \mathrm{O}_{3}$ - treated $\mathrm{NiO}$-cordierite containing $20 \% \mathrm{NiO}$ showed measurable catalytic activity in $\mathrm{CO}$ oxidation by $\mathrm{O}_{2}$ carried out at $200{ }^{\circ} \mathrm{C}$. The activity suffered a serious drop in the catalytic activity upon increasing calcination temperature from 350 to $600{ }^{\circ} \mathrm{C}$.

\section{REFERENCES}

[1] Radwan, N. R. E.; El-Shobaky, G. A.; Fahmy, Y. M. Cordierite as catalyst support for cobalt and manganese oxides in oxidationreduction reactions. Appl. Catal. A, 2004, 274, 87-99.

[2] Liu, Z.; Woo, S. I. Recent advances in catalytic de $\mathrm{NO}_{\mathrm{x}}$ science and technology. Catal. Rev. Sci. Eng. 2006, 48, 43-89.

[3] Parmaliana, A.; Arena, F.; Frusteri, F.; Coluccia, S.; Marchese, L.; Martra, G.; Chuvili, A. L. Magnesia-supported nickel catalysts : ii. surface properties and reactivity in methane steam reforming. $J$. Catal. 1993, 141, 34-47.

[4] El-Molla, S. A. Dehydrogenation and condensation in catalytic conversion of iso-propanol over $\mathrm{CuO} / \mathrm{MgO}$ system doped with $\mathrm{Li}_{2} \mathrm{O}$ and $\mathrm{ZrO}_{2}$. Appl. Catal. A, 2006, 298, 103-108.

[5] Andreini, A.; DeBoer, M.; Vuurman, M .A.; Deo, G.; Waches, I.E. Selective catalytic reduction of nitric oxide with ammonia on vanadia/alumina catalysts. Influence of vanadia loading and secondary metal oxide additives. J. Chem. Soc., Faraday Trans., 1996, 92, 3267-3272.

[6] Lemenidou, A. A.; Stambouli, A. E. Catalytic and non-catalytic oxidative dehydrogenation of n-butane. Appl. Catal. A, 1998 ,171, 325-332.

[7] El-Shobaky, G. A.; EL-Khouly, S. M.; Ghozza, A. M.; Mohamed, G. M. Surface and catalytic investigations of $\mathrm{CuO}-\mathrm{Cr}_{2} \mathrm{O}_{3} / \mathrm{Al}_{2} \mathrm{O}_{3}$ system. Appl. Catal. A, 2006, 302, 296-304.
[8] El-Molla, S. A.; Hammed, M. N.; El-Shobaky, G. A. Catalytic conversion of isopropanol over $\mathrm{NiO} / \mathrm{MgO}$ system doped with $\mathrm{Li}_{2} \mathrm{O}$ Matter Lett. 2004, 58, 1003-1011.

[9] Khezrabadi, M. N.; Naghizadeh, R.; Assadollah, P.; Mirhosseini, S. $\mathrm{H}$. An investigation on the properties and microstructure of mullitebonded cordierite ceramics. J. Ceram. Process. Res., 2007, 8, 431434.

[10] Subramanian, M. A.; Corbin, D.R.; Chowdhry, U. Better ceramic substrates through zeolites. Bull. Mater Sci., 1993 , 16, 665-678.

[11] Trimm, D. L. Materials selection and design of high temperature catalytic combustion units. Catal Today, 1995, 26, 231-238.

[12] Skoglundh, M.; Johansson, H.; Löwendahl, L.; Jansson, K.; Dahl, L.; Hirschauer, B. Cobalt-promoted palladium as a three-way catalyst. Appl. Catal. B, 1996, 7, 299-319.

[13] Shigapov, A. N.; Graham, G. W.; McCabe, R.W.; Peck, M.P.; Jr, H.K.P. The preparation of high-surface-area cordierite monolith by acid treatment. Appl. Catal. A, 1999, 18, 137-146.

[14] El-Shobaky, H.G.; Fahmy, Y.M. Cordierite as catalyst support for nanocrystalline $\mathrm{CuO} / \mathrm{Fe}_{2} \mathrm{O}_{3}$ system. Mater. Res. Bull. 2006, 41, 1701-1713.

[15] El-Shobaky, H.G.; Fahmy, Y.M. Nickel cuprate supported on cordierite as an active catalyst for $\mathrm{CO}$ oxidation by $\mathrm{O}_{2}$. Appl. Catal. B, 2006, 63, 168-177.

[16] Liu, O.; Liu, Z.; Zhu, Z.; Xie, G.; Wang, Y. $\mathrm{Al}_{2} \mathrm{O}_{3}$-Coated Honeycomb Cordierite-Supported $\mathrm{CuO}$ for Simultaneous $\mathrm{SO}_{2}$ and NO Removal from Flue Gas: Effect of $\mathrm{Na}_{2} \mathrm{O}$ Additive. Ind. Eng. Chem. Res., 2004, 43, 4031-4037.

[17] Cullity, B.D. "Elements of x-ray diffraction", $2^{\text {nd }}$ Ed , AddisonWesley Publishing Co, Reading, MA, USA, 1978.

[18] El-Shobaky, G.A.; Ghozza, A.M.; El-Warraky, A.A.; Mohamed, G.M. Surface and catalytic investigations of $\mathrm{Co}_{3} \mathrm{O}_{4}-\mathrm{MoO}_{3} / \mathrm{Al}_{2} \mathrm{O}_{3}$ system. Colloids Surf. 2003, 219, 97-111.

[19] Youssef, A.M.; El Kherbawy, M.A.; Samra, S.E. Effect of irradiation with gamma-rays on the surface and catalytic properties of $\mathrm{SiO}_{2}-\mathrm{Al}_{2} \mathrm{O}_{3}$ and $\mathrm{Li}_{2} \mathrm{O}$-impregnated $\mathrm{SiO}_{2}-\mathrm{Al}_{2} \mathrm{O}_{3}$ systems. Radiat. Phys. Chem. 1992, 40, 559-563.

[20] Youssef, A.M.; El-Hakam, S.A.; El-Shobaky, G.A. Effect of gamma-irradiation on catalytic activity and selectivity of $\mathrm{CuO}$ $\mathrm{Al}_{2} \mathrm{O}_{3}$ solids . Radiat. Phys. Chem. 1992, 40, 575-578. 